\title{
リチャード・ノイトラの建築観と日本 \\ RICHARD NEUTRA'S ARCHITECTURAL THOUGHT AND JAPAN
}

\author{
玉田浩之* \\ Hiroyuki TAMADA
}

\begin{abstract}
This paper aims at an investigation of the relationship between Richard Neutra and Japan. At first, this study focuses on the intersection between Vienna and Japan, emphasizing of Japonisme in Vienna. Secondly, this study examines Neutra's interest by making clear what he has found in Japan. Finally, this study analyzes how Japan affected Neutra's architectural thought. As a result of these analyses, this paper reveals that he emphasized the significance of Japanese traditional houses, landscape and gardens. He especially has learned from a view of nature and other traditional aspects of Japan. This paper points out that Japan played some important roles on his architectural theory.
\end{abstract}

Keywords: Richard Neutra, Japan, Vienna, Japonisme, modernism, regionalism リチャード・ノイトラ、日本、ウィーン、ジャポニスム、モダニズム、地域主義

1.はじめに

近代建築運動史においてリチャード・ジョセフ・ノイトラ (Richard Josef Neutra, 1892-1970) は欧州のモダニズム建築をアメリカで早期 に実現した人物として評される。うしたノイトラへの注目の多くは 1932 年のニューヨーク近代美術館 (MoMA)にて行われた「近代建築： 国際展覧会」に基づいている1。しかしその後、1982 年にノイトラの 詳細な評伝が出版されたこと、同年 MoMA において展覧会が開催さ れたことにより、アメリカのモダニズム建築の先駆者でありながら、 カリフォルニアの地域的な近代建築の発展に重要な貢献をした人物 として再評価が進められた2。近年では、欧州出身のモダニズムの建 築家という位置づけのみでは捉えきれない彼の建築観の特異性が注 目されつつあり 3 、とりわけ近代アメリカ建築における地域主義者と しての評価が高まっている4。

本稿は、これまであまり注目されることのなかったノイトラの日 本に対する理解を通して、欧州のモダニズムの文脈からだけでは捉え きれない彼の建築観を明らかにしようとするものである゙。このこと は、アメリカにおけるモダニズム展開期の地域主義を評価し直すこと にもつながる論点を含んでおり、注目に值する。ノイトラは 1930 年 に初来日を果たし、その後 1951 年と 1952 年にも来日し、講演を行う
と同時に各地を歴訪している。初来日以降ノイトラは再三日本につい て言及しているだけでなく、積極的に日本を評価し、「日本に学んで いる」と述べていることから、日本訪問は彼の建築観の形成において 重要な意味を持ちえたと考えられる。したがって、ノイトラが具体的 に日本の何に興味を示し、日本に対してどのような理解を示したのか について検討することは、彼の建勧観を把握するうえで重要であると 思われる。

ここでは、ノイトラの建築観を日本との関係において明らかにす ることを目指し、最初の来日を中心として、来日前、来日時、来日後 の三つの時期に分けて考察する。ここで三期に分けて考察するのは、 ノイトラの日本に関する言説には、初来日に関する言及が多くみられ、 初来日が彼の建築観において大きな刺激になっていたと考えられる からである。本稿では、まずは、来日以前のノイトラと日本の接点を 考察することにより、日本受容の背景を明らかにする。つぎに、これ まで明確にされていなかったノイトラの初来日時の言説と行動を時 系列に沿って整理を行56。そして初来日以降、彼が日本に言及した 講演内容や論文を検証することによって日本に対する関心の所在を 明らかにし、初来日以後にノイトラが展開してきた建築論との関連か ら彼の日本に対する理解について考察する。

* 京都工芸繊維大学大学院工芸科学研究科 大学院生 -工修 Graduate Student, Graduate School of Science and Technology, Kyoto Institute of Technology, M. Eng. 


\section{2. 来日まで : 日本受容の背景}

まずは、ノイトラの来日までの経歴について概観しておきたい。 ノイトラは 1892 年ウィーンに生まれ、1911 年にウィーン工科大学に 進学し、大学二年目からアドルフ・ロースの先進的サークルに加わり、 大学とサークルの両方から建築を学んでいる。1914 年以降の数年間 は戦争によって学業の中断を余儀なくされるが、1918 年には卒業し ている。その後チューリッヒの造園家グスタフ・アマンのもとで働き つつ、スイス工科大学で建築家カール・モーザーのクラスに短期間だ が学んでいる。そして、彼はベルリンのエーリッヒ・メンデルゾーン の事務所で働いたのち、1923 年にアメリカに移住することになる。 渡米後は、シカゴのホラバート・アンド・ローチの事務所やフランク・ ロイド・ライトのもとで働き、その後、ロサンゼルスでのルドルフ・ シンドラーとの協働を経て 1925 年に独立する。1930 年には、第 3 回 近代建筑国際会議 (Congrès Internationaux d'Architecture Moderne: CIAM）のアメリカ代表となり、ブリュッセルでの国際会議へ向かう 途中で初めて日本を訪れることとなる。

さて、来日以前のノイトラはどのようにして日本に関心を持つよ うになったのであろうか。その時期は明確に特定することはできない が、当時の状況からその一端をうかがい知ることができる。20世紀 の初頭にウィーン工房の主催者ヨーゼフ・ホフマンの事務所に勤め、 また、京都の日本インターナショナル建築会の活動を通してノイトラ と親交を深めていた上野伊三郎は、ウィーン時代のノイトラについて つぎのように回想している。

「ノイトラがウィーンで属して居たスッルナード、フランクの団体は前述の 通り独墺機能主義グループの尖端であって、ノイトラはこのグループから出 た最大の天才であり、最も自由な働きをした建築家である。このグループは 日本とチャイナの古美術には䛈の外の尊敬を払い、殊に日本の古美術を敬服 研究していたのである。」

ここでいう独墺機能主義のグループとは、アドルフ・ロースを含 む芸術家たちの集団のことである。この証言からノイトラが具体的に どのような活動をしていたかは定かでないが、少なくとも彼の所属し ていたグループは日本美術を積極的に評価していたことがわかる8。 したがって、20 世紀の初頭にノイトラは日本古美術に関する情報や 作品を見聞きしていた可能性がある。

日本美術や工芸、建築を参照した芸術運動はジャポニスムとして知 られている。とりわけ 19 世紀末から 20 世紀初頭にかけてのウィーン は、ジャポニスムが隆盛を極めた時期であった。このような時代にあ って、ノイトラはロースらのグループに加えて、日本美術に㑯倒して いた芸術家たち、グスタフ・クリムトやエゴン・シーレと親交を媣め ていたのである9。この学生時代の芸術体験は、ノイトラに影響を与 えずにはおかなかったと思われる10。イトラは、この時期に建筑的 ドローイングとは別に多くのスケッチやデッサンを描いているが、そ こには世紀末ウィーンの画家たちの影響が色濃く映し出されている。
1910 年代のノイトラのスケッチは退廃的な雾囲気を漂わせており、 その画風はクリムトやシーレのものに近似している。また、金地や無 地の背景、図像を平面的に処理する手法などは日本の屏風絵に近い。 学生時代に描かれたものを見る限り、ウィーンのジャポニスムとノイ トラは無関係ではない（図1３）。しかしながら学生時代にノイトラ は日本美術について言及をしておらず、直接的な影響を示す関連記述 を見つるけることはできない。したがって、ノイトラのデッサンやス ケッチにみられる日本的手法は日本美術への直接的な接触によるも のというよりも、むしろジャポニスム影響下のウィーンの画家たちの 作品を通して体得したものと考えるのが妥当であると思われる。

ノイトラはウィーンで既に日本美術と出会っていたと考えられる が、直接的に日本美術に触れる機会として明らかなのは、渡米後のフ ランク・ロイド・ライトの事務所でのことである。ノイトラと同時期 にライトの事務所に在籍していた土浦亀城夫妻によれば、ライトの事 務所では、週末毎にライトによって收集された浮世絵や日本画の講義 が行われていたという ${ }^{11}$ 。ライトの事務所であるタリアセンには多数 の浮世絵、日本画、ふすま絵が飾られていたことからも、ノイトラが ライトの浮世絵などの日本美術コレクションを直接目にしていたの は確実である ${ }^{12}$ 。また、後述するように、来日時のノイトラは広重や 日本画について語っている。このことから、彼は直接的な日本美術の 接触によって 1930 年までに日本美術に関心を持つようになっていた と考えられる ${ }^{13}$ 。

一方、日本建築について触れる機会はあったのだろうか。管見で は直接的に彼が日本建築について見聞きしたと記す文献は見当たら ない。しかしながら、ノイトラは第一次世界大戦中に日本建策を想起 させる注目すべき事績を残している。第一次世界大戦勃発直後の 1914 年にバルカン半島へと出征したノイトラは、その道程で「将校 の茶室 Officer's Tea House」（1915 年）（図4）を設計している。

この茶室は無装飾の平坦な面と柱と梁で構成され、壁から露出し た柱は背後の白壁によって強調されている。そして一定の連続する柱 によって、視覚的な規則性が表現されている。ニューヨーク近代美術 館の建築デザイン部門のアーサー・ドレクスラーが指摘したように、 この茶室にみられる表現は桂離宮のような日本の伝統的な建築の視 覚的特質と共通する ${ }^{14}$ 。この共通性は、ノイトラの日本受容について 考察するうえで注目される。ノイラはこの時点では、まだ日本建築 に関する知識を十分に持っていなかったと考えられるが、彼の最初の 実作となるこの茶室は、日本建築の特徴に近接していたのである。

ノイトラは 1930 年の来日を振り返って、「私は（中略）日本から の最初の招待を受けとってそこに到着したとき、突然、まるで我が家

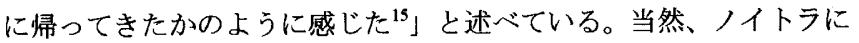
とって日本は異国の地であるはずであった。ところがノイトラは異国 の地といら感覚よりも、むしろ日本に対する強い親近感を抱いていた

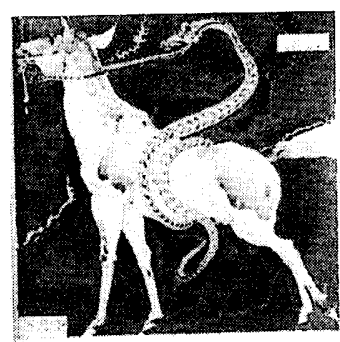

図 1 : 馬と蛇（1915）

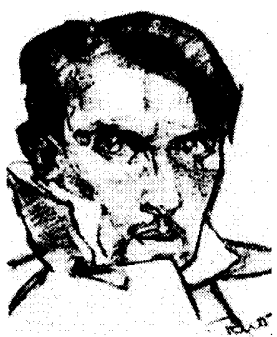

図 2 : 自画像（1917）

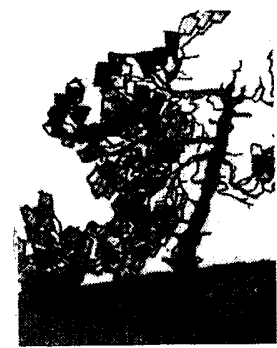

図 3 : 風景画 (1918)

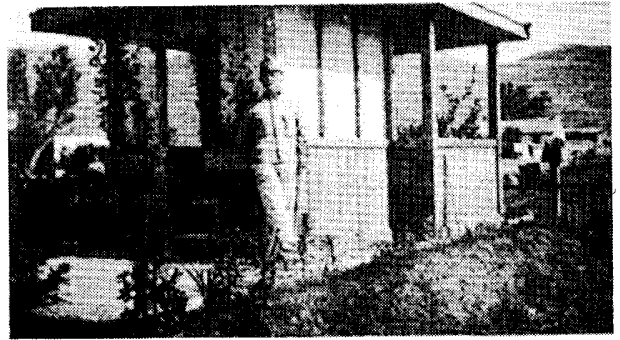

図 $4:$ 将校の茶室（1915） 
という。ウィーンのジャポニスムとライトの日本趣味という二重の契 機によって育まれた感性は、来日直後のノイトラに日本に対する親近 感を抱かせるに至ったと考えられる ${ }^{16}$ 。来日までの日本芸術との接触 が直接的、間接的のいずれであったにせよ、ノイトラは日本に対する 高い関心と強い親近感を持って日本を受容することになったと考え られる。

\section{3. 来日 : 日本の特質の探求}

先述のとおり、ノイトラは 1930 年に CIAM のアメリカ代表として 出席するためにブリュッセルへと向かい、その旅の途中で日本に立ち 寄っている。ノイトラは、ライトの事務所で知り合った土浦亀城から 招待を受けるかたちで、来日したようである。来日時のノイトラは、 近代建築に関する講演を行う傍ら、日本建築の視察を精力的に行って いる。したがってノイトラの来日には、近代建築の推進と日本の視察 という、少なくとも二つの目的があったと考えられる ${ }^{17} 。$

まずは、当時の建築家としてのノイトラの立脚点を把握するために 初来日時の講演内容を検討しておきたい。来日直後のノイトラは、東 京で国際建築協会が主催する「新建築の意義と実際」 ${ }^{18}$ と題する講演 を行っている。この講演でノイトラは著書『アメリカは如何に建てる かWie baut Amerika?』や『アメリカ Amerika』で論じた内容を紹介し つつ、来るべき「新建築」について述べている19。この講演はいわゆ る欧米の機能主義の考え方を紹介するものであった。また、日本イン ターナショナル建築会が主催した「インターナショナル建築」 ${ }^{20}$ と題 する大阪の講演会では、第 2 回 CIAM のテーマであった「最小限住宅」 の概念を解説し、大衆のための建築をつくることが将来の建築の指針 となると述へ、とくに建築に扔ける合理性と衛生面、すなわち空気と 光の必要性を強調している21。このように当時のノイトラは CIAM 代 表としての見解を述べて、その理念の重要性を訴えている22。 ノイト ラはこれらの講演を通して、欧州のモダニズムを標榜する立場を鮮明 にしているといえる。したがってこの時点では、彼はモダニズムのも つ機能主義の観点から日本を捉えようとしていたと考えられる。

では、ノイトラは日本に何をみて、如何なる評価をしていたので あろうか。ここでは、1930 年のノイトラの日本での足跡をたどり、 各地で残した感想を考察することにより彼の日本に対する理解につ いて考察していきたい。日本での具体的な視察内容については、翌年 1931 年のドイツ工作連盟の機関誌『フォルムDie Form』に掲載され た、ノイトラによる一連の日本建築に関する記事と写真からその概要 をうかがい知ることができる23。同誌をみる限り、東京では、土浦亀 城の自邸、堀口捨己の吉川邸や吉田鉄郎の馬場邸、東京周辺の寺社建 築や同潤会アパート、山田守の東京聥信 省電話局、アントニン・レーモンドによる ソビエト大使館など、いわゆる日本のモ ダニズム建築を中心に見ていたと考えら れる。ただし視察時のノイトラは「最近 の日本の様式建築についてどう思うか」 という質問に対して、けああジャパニーズ クラシックか（中略）あんなものを気に するのはよろしくない」と述べており、 様式建築はいくつか見ていたものの、そ れらには全く関心を持たなかったようで
ある ${ }^{24}$ 。ノイトラの『フォルム』誌の記事は、当時の日本の建築の動 向を伝えることを主眼としているため、そのほかの視察内容について は、うかがい知ることができない。しかしながらインターナショナル 建築会の活動記録とカリフォルニア大学ロサンゼルス校のアーカイ ブが所藏する日本滞在中に描かれたスケッチから、日本でのノイトラ の動きを跡づけることができる25。

日本での 3 度の滞在日程と当時のスケッチの内容をまとめると順 に表 1 と表 2 のようなる。表 1 より初来日時にノイトラは東京だけ でなく、日光、箱根、鎌倉、京都、奈良、大阪を訪れて、各地で伝統 的な建築をみていたことがわかる。つまり、ノイトラは当時の新しい 建築以上に、いわゆる伝統的な建築の視察を行っている。表 2 をる と、日本の人々の日常生活を描くほか、明治神宮では森に佇む社殿を、 日光と箱根では町並みを、奈良では東大寺からみた風景などを描いて いることがわかる。これらからノイトラの日本特有の生活様式、伝統 的な建築や景観、とりわけ鳁や和室に対する関心が読みとれる。

前揭の『フォルム』誌の論考では、衣服や生活様式の関係、すな わち和服と疊の上での生活が密接で機能的な関係にあること、そして 家具や建具、畳が住宅を支配する規格にもとづき、合理的な関係性が 築かれていることに注目している。一方、同誌では、伝統的な建築や

1930 年 (昭和 5 年)

\begin{tabular}{|c|c|c|}
\hline 日時 & 場所 & 内容 \\
\hline 6月9日 & 横浜港 & 横浜港入港 \\
\hline 6月 10 日 & 東京 & 東京市内観光 浅草 明治神宦 赤坂にて晚餐 \\
\hline 6月 11 日 & $\begin{array}{l}\text { 東京講演会「新建築の意 } \\
\text { 義と実際」 }\end{array}$ & \begin{tabular}{|l} 
東京国民新聞社講堂 \\
國際建築協会主催 国民新閏社後援 発起人: \\
土浦亀城 山田守 岸田日出刀 石本喜久治
\end{tabular} \\
\hline 6月 $12-13$ 日 & 日光、箱根 & \\
\hline 6月 14 日 & 箱根 夜京都着 & 京都市内見物 都ホテル泊 \\
\hline 6月 15 日 & 京都 & 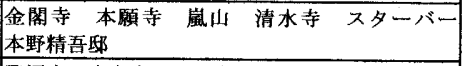 \\
\hline 6月 16 日 & 奈良・大厉 & 興福寺 東大寺 大阪市内見物 \\
\hline 6月 17 日 & \begin{tabular}{|l|} 
大阪 \\
新興建築講演会「インタ \\
ーナショョナル建築」
\end{tabular} & $\begin{array}{l}\text { 大阪市役所 中央市場 今宮アパートメント 大阪 } \\
\text { 城 毎日新聞社諾堂 日本インターナショナル } \\
\text { 建築会主催毎日新聞社 日本建築協会後援 }\end{array}$ \\
\hline \multicolumn{3}{|c|}{1951 年(昭和 26 年) } \\
\hline 12月 10 日 & グアム島発 羽田着 & 口バート・アレギザンダーと共に来日 三日滞在 \\
\hline 12 月 13 日 & $\begin{array}{l}\text { 東京講演会「日本の建箖| } \\
\text { 家諸君に」 }\end{array}$ & 読涜ホール 國際建案協会 日本建築学会 譡売 新 \\
\hline \multicolumn{3}{|c|}{1952 年（昭和 27 年） } \\
\hline 5月9日 & \begin{tabular}{|l|} 
京都 \\
大阪講演会「自然に帰れい」
\end{tabular} & \begin{tabular}{|l} 
景都御所 桂離宫 大德寺 \\
朝日会館 日本建築偾会主催 朝日新䦥後援
\end{tabular} \\
\hline 5月 10 日 & 伊勢・奈良 & 伊勢神宫 東大寺 \\
\hline 5 月 11 日 & 京都 & 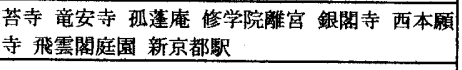 \\
\hline 5 月 12 日 & 東京 & \\
\hline
\end{tabular}

表 2:アーカイブ所葴の日本旅行のスケッチ

\begin{tabular}{|c|c|c|}
\hline 年期および地名 & 内容 & アーカイプ番号 \\
\hline Tokyo 1930 & 麦うら帽子をかぶった着物姿の男性 & 1179: box3 \#220 \\
\hline untitled & 日常的にみられる着物姿の女性 & 1179: box5 \#1083 \\
\hline untitled & 子供老背負う女性 & 1179: box $5 \# 1084$ \\
\hline Meiji SHR, Tokio, 1930 & 明治神宫の鳥居 & 1179: box $\# 1091$ \\
\hline untitled & 明治神宣本殿 & 1179: box 51092 \\
\hline Osaka 1930 & 着物姿の女性 & 1179: box $\#$ \#1094 \\
\hline $\begin{array}{l}\text { Hakone-Machi-Tokaido } \\
1930 \text { Mikaeri Matsu }\end{array}$ & 見返り松越しにみる箱根の湖と山並 & 1179: box 5 \#1102 \\
\hline untitled & 上半身大の正面加みた着物姿女性 & 1179: box $5 \# 1106$ \\
\hline Tatami Hakone 1930 & 和室の睘、床、天井を含む透視図 & 1179: box 5 \#1108 \\
\hline Nara & 東大寺二月堂からみた家並みか & 1179: box $5 \# 1162$ \\
\hline Tokondo NARA & 五重塔 & 1179: box5 \#1215 \\
\hline Sokothro 1930 & 海からみた山なみ & Box $1287 \# 1099$ \\
\hline Chuzenji & 湖越しに描かれた山なみ & Box $1287 \# 1208$ \\
\hline Nikko 1930 & 商店街の町並み & Box $1287 \# 78$ \\
\hline Trip on Japan 1930 & 電車为らみた田園風景か & Box $1287 \# 3$ \\
\hline Montery Ginza & 書院つき和室で萊をたてる和装女性 & Box $376 \# 466$ \\
\hline Later Travel & 神社の鳥居と門 & Box $1286 \# 211$ \\
\hline
\end{tabular}


景観については言及されていないが、こうした関心については、京都 の視察時に残した感想からうかがい知ることができる。京都では、本 願寺、清水寺、金閣寺、峝山などを視察しているが、とりわけ雨の降 る嵐山の風景を目にして、ノイトラはつぎのように述べている。

「広重や日本の画が雨の風景を描くのは、日本の風景画が雨のために斯くも 一種の美しい趣きを有するからである」 ${ }^{26}$

このようにノイトラは日本特有の景観に関心を示し、自然風景に 対する高い感受性が浮世絵や日本画の世界をつくりだしているのだ と理解している。同時に、ここにはノイトラの日本の人々の風景に対 する美意識への共感がうかがえる。さらに夕暮れの清水寺では、建築 全体と自然の風景の調和に感嗼し、これを高く評価している ${ }^{27}$ 。以上 のような日本の自然風景や建築的景観に対する評価は、ノイトラが日 本の風景の美しさ、そして、その風景と建築が調和する様子を日本の 注目すべき特質として理解していたことを示している。

初来日時のノイトラの関心については、晚年に書かれた自伝『ラ イフ・アンド・シェイプ Life and Shape』で明確に述べられている。

「金持ちと貧しい人、都市に住む裕福な人と農民、彼らは皆、空間次元にお

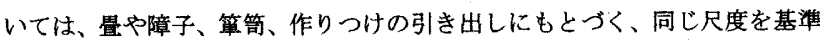
としていた。細やかな部分の仕上け゚、細エはシンプルで規格に合っており、 驚くほど美しい仕事を見せている。それらには本当に基本となる関連性が明 らかに存在している!私はこれら全てのものを求めて努力していた。そして、 私はもはやひとりではないのだ。」 ${ }^{28}$

ここでは日本の箪劄・畳・建具などにみられる規格統一と、その 技術力と芸術性が評価されている ${ }^{29}$ 。さらに、これら日本の標準化に みられる特質があらゆる階層の人々に適用されていることが、とりわ け高く評価されている。

このようなノイトラの積極的な日本に対する評価には理由があっ たと思われる。ノイトラが参画していた CIAM は 1920 年代後半を通 して、住宅の不足と住環境の改善を目的として万人のための建築空間 をつくるための設計手法を探求していた ${ }^{30}$ 。標淮化と合理化は 1927 年のラ・サラ宣言で最初に揭げられた項目であり、ノイトラが関心を 寄せていた項目でもあった。ノトラは欧州の探求していた設計手法 が日本の伝統的建築に内在していること、そして、それらが日本人の 生活に役立つ手だてとして用いられ、日本に根づいていることを感じ 取ったがために、このような日本に多大な関心と共感を寄せたのであ ろう。換言するならば、ノイトラは欧州のモダニズム建築の志向と日 本の伝統にみる特徽の共通性に注目し、その共通性ゆえに日本に対寸 る高い評価をしたと思われる。ノイラは日本の特質の探求を通して、 みずからが目指す建築の方向性に対して確信を深めることになった と考えられる。

一方で、ノイトラは自伝のなかで、つぎのようにも述へてている。

「どんより孀ったある朝、我々は横浜比到着した。(中略) 当時、東京と大 阪は、現在の大きさの四分の一しかなく、京都は人が触れた事がないかのよ うに、古の状態を保っていた。すべてが私自身のこれまでの環境と信じられ ないくらい違っていた。だが、空間と自然の扱いについての私の感賞にとっ ては、すべてがとても近しかった。」 ${ }^{31}$

このように初めての来日で、ノイトラは日本の「空間と自然の扱 いに対して親近感を覚えていたという ${ }^{32}$ 。ここでいう「空間と自然 の扱いとは、京都で残した感想と合わせて判断するならば、日本の 風景と建物の調和の妙を指しているものと考えられる。また、この， イトラの日本に対する親近感は、日本を欧州の機能主義の文脈で捉え るだけでなく、ノイトラ自身の建篗観を基淮にして述べたものと考え
られる。ノイトラが日本に対して抱いた共感は、機能主義では捉えき れない彼の建築観を知るための手がかりとなろう。日本の「空閒と自 然の扱いに関しては、再来日及び再々来日の講演内容にうかがうこ とができるが、初来日以後の発表論文や著書において、具体的な論考 の対象として幾度も取り上げられるため、以下で論ずることにする。

\section{4．来日後 : 初来日後の論考にみる日本}

帰国後のノイトラは個人住宅を多く手がけると同時に、アメリカ 合衆国住宅局のコサンルタントとしても活動していた。彼はその活動 の一環として、論文「今日の国内状況 The Domestic Setting Today ${ }^{33}$ 」 を発表し、自己の住宅生産に対する見解を述べている。ノイトラは論 文の冒頭で、アメリカの「工業化の新しい状況」を前提として、住宅 生産のためには標準化を推し進めるべきだと説いている ${ }^{34}$ 。そして、 その標淮化に対する主張の正当性を論じるにあたって、ノイトラはつ ぎのように日本の住宅を引き合いに出している。

『たとえば、日本の住宅建設において、美しさや魅力的な多様性は、基本と なる寸法と材料の何千年にもわたる標準化によって、損なわれることは全く なかったのである。」 ${ }^{35}$

標準化を進めるうえで問題となるのは、住宅が無味乾燥な画一化 へ向かうことへの危惧であった。ノイトラは日本の標準化を例にとる ことによって、その危惧を取り除こうとしている。彼は、美的要素と 多梯性を失うことなく展開した標準化の具体例が、日本にあると考え ていた。つまり来日後のノイトラにとって日本の標準化にみた特質は、 アメリカの工業化住宅の生産の実現可能性を示寸うえで、参考にすべ き事例となっていたのである。

一方、この論文では、日本の標準化の特質とは別に、日本の住宅 の庭について言及している点が注目される。ノイラは日本の住宅の 庭にどのような特質をみていたのであろうか。ここで、ノイトラは今 後のアメリカの住宅建設に要求される基本原理を三つ挙げている。 それは、1）外部とのより親密な関係、2）空間の快適性と経済性の 組み合わせ、3）清潔さに対する備えである。ノイトラはこの第一項 に関する記述の冒頭で、つぎのように述べている。

「現代のテクノロジーは住宅の内側に、自然で快適な戸外の状況をつくるこ とができる。同時に、居住地の周囲の庭園空間は飾りとしてだけでなく、本 当に快適な生活圈となるに違いない。伝統的な日本住宅の事例は、ごく小さ な裹庭でさえも居住者の近くに普遍的な自然の魅力や多くの清涼剂をもた らすということを示している。」 ${ }^{37}$

このようにノイトラは「外部とのより親密な関係」を築くものと して庭に注目し、庭のもつ意義を再考している。ノイトラはそれまで 飾りとして存在していた庭は、現代のテクノロジーの進歩によって、 眺められるためだけでなく、生活のための空間になると捉えている ${ }^{38}$ そして、生活のための空間としての庭の具体的な意味を、日本の住宅 の庭にみているのである。ここでは、伝統的な日本の小さな裏庭は自 然と居住者を近づける装置として認識され、また、庭は小さくとも居 住者を回復させる清涼剂として機能するものと理解されている。この ことから、ノイトラが日本の住宅の庭にみたものは、物理的に外部空 間を取りこむことによって人間に与えられる心理的効果というべき ものであったことがわかる。

ノイトラが「外部空間とのより親密な関倸」を築くもののひとつ として庭に注目し、その具体的な意味を日本の庭に見出していたこと を考えるならば、日本の住宅の庭に見出した特質が、当時のノイトラ 
の住宅に関わる建築理念と共通していたと考えることができる。

さらに、その後の著書にもノイトラの日本の住宅の庭への言及を 見出すことができる。1951 年の著書『敷地の神秘と現実 Mystery and Realities of the Site ${ }^{39} 』 に お い て 、$ 自然景観を重視したデザインを論じ るなかで、以前と異なる観点から日本の住宅の庭に対する理解を示し ている。ここでノイトラは「日本の伝統的な都市」にある住宅では、 「宝石のような宇宙や理想的な景観の断片が小さな裏庭で巧みにと らえられている」と述べている40。以前と同様に日本の裹庭に着目し ているが、ここでは、宇宙や景観といった建物の周囲に存在する空間 的な広がりを感じさせる何らかの断片が巧みにとらえていることに 対して評価がされている。

では、なぜこうした評価に至ったのであろうか。ここでは、これ 以上、日本の庭についての説明は加えられていないが、この著書が敷 地の神秘性を積極的に取り込もうとする姿勢を打ち出したものであ ることを考えると、日本の庭に対する評価の意味が了解されてくる。 すなわち、ノイトラにとって「建物は敷地の持つ精神性を共有しなけ ればならない41」ものであったことを考えるとき、日本の庭は、敷地 の持つ精神を「巧みに」汲み取ったものとして評価されていたとみる ことができる。このような、建物が存在する敷地の持つ精神性を共有 しなければならないという意識を、ノイトラは以前から基本的な姿勢 として持っていたようである。同論文でノイトラは、これまでの自分 の建筑に対する姿勢について、つぎのように述べている。

「現代建筑は、特殊で地域的な環境の多様性に無関心で、機械化や標準化さ れるものとして進攻してきた。しかし私はいらも問題となる個別の特質に多 くの魅力を感し、鼓舞されてきたのである! ${ }^{42}$

ここに示されるように、ノイトラが常に地域的な環境の特質に対 して注意を払っていたことを考え合わせるならば、彼の日本の住宅の 庭に対する評価は、建物が敷地のもつ特質を汲み取っていなければな らないという彼の建築理念に基づいていたと考えられる。

また、こうしたノイトラの建築に対する智に関連して、その他 にもノイトラが日本に共感した例をみつけることができる。彼は日本 建築協会が主催する「自然に帰れ 自然の捉え方に注目して、つぎのように述べている。

「日本は自然を愛し、その美しさを保持しつづけたところの世界にも稀な国 のひとつであります。神社や寺院などすべて自然睘境のうちに置かれていま す。お国では、どんな子供でも滝や山などを眺め、自然の美しさを味わって 㧍ります。幼いときから自然に親しみ、自然を楽しんでくらすよう訓練され ております。建築家が、自然と生活とを融和せしめねばならぬということは、 ここに事新しく説くまでもありません。」 ${ }^{44}$

ここで述べられるのは、今後の建築家に求められる姿勢について である。建築家は自然と生活を親しい関係にしてゆくべき存在である という考えを論じるにあたって、日本の人々が古くから自然に親しむ 生活を保持してきたことに注目している。換言するならば、ノイトラ は日本という地域の文化的特徽のひとつを日本の自然の捉え方に見 出しているといえる。このような日本の自然の捉え方はノイトラ自身 の自然の捉え方と同じものと認識しているばかりか、建築を思考する うえで重視すべき姿勢だと説いている ${ }^{45}$ 。したがって、ノイトラにと って日本の伝統にみられる自然観は、共感といら意識を超えて、来日 後の彼の建築観の意義や実現可能性を思考するうえで、参照すべき対 象としての重要な役割を担っていたと考えられる。ノイトラが日本に 見たものは、彼の建策観の具体的な展開だったのではないだろうか。
ノイトラの日本に対する共感は、初来日の1930 年加ら1950年代 初頭まで保持されていたことがうかがえるが、それまで日本の影響に ついては明言されることはなかった。しかし、1951 年の再来日時の 「日本の建筑家諸君に」と題した講演で、ノイトラは日本から受けた 影響について、つぎのように述べている。

「日本の古いりっぱな歴史は、わたくしの建築作品をつくる上に非常に参考 になっております。（中略）日本の優れた風景がわたくしにいか沉つよく印 象つけたかを括話ししたいと思います。じっさいそれ惊わたくしの建築観に 強い影響を与えております。」46

ここで注目されるのは、ノイトラが日本を参考にしていると述べ るだけでなく、日本が彼の建策観に強い影響を与えていると認識して いる点である。このことは、初来日以降のノイトラにとって日本の影 響が大きかったこと、そしてその影響は彼の建築観においてこそ、み られることを伝えている。

彼の建築観に与えた日本の影響については、同講演のなかで、日 本は風景や自然に対する尊敬の念を伝統的に保持してきたこと、標淮 化や空間の融通性が伝統的に成立していること、そして日常生活と建 築が渾然一体となっていることを挙げている47。これらは初来日時に 注目した内容と同じものである。しかしこの講演では、こうした日本 の誇るべき伝統は継承されるべきであると付计加えている点が注目 される。これまでみてきたよらに、日本の伝統的な要素こそが、来日 を通じて彼が理解を示してきたものであった。

日本に言及したノイトラの言説を合わせてみるとき、彼が来日を 通じて受容したものは、日本の外観上の意匠にではなく、日本の伝統 にみられる合理性や機能性、そして自然の报い方にあったということ ができる。換言するならば、ノイトラは日本の造形の背後にある抽象 的性格を理解し、受容していたといえる゙。来日後のノイトラの作品 に一見して日本的な意匠を認めるのが困難なのは、こうした理由から であろう。逆に、ノイトラが日本から受容したものは、日本の造形の 抽象的性格であったがゆえに、表面的な造形にではなく、建築観に影 響を与えたと考えられるのである。

\section{5.おわりに}

以上、来日前、来日時、来日後に分けて、ノイトラの日本に対寸 る関心の所在を中心に考察した。来日前には、ウィーンのジャポニス ムとライトの日本趣味を通して日本受容の素地を育み、これらは来日 時のノイトラに、日本に対する親近感をもたらしたと思われる。その 後、実際に来日することによって、実体験に基づいた理解が進められ た。来日を通してノイトラが日本に関心を示した点は、日本の伝統的 な建築にみられる標準化の有効性、自然と建築の関係にみる親近性、 そして生活と建築の合理的な関係性であった。来日娞には、自身の建 筑観を論じるうえで、日本の住宅にみられる敷地への配慮や自然の报 い方に言及していた。したがってノイトラは日本を理解する過程で日 本の造形意匠の形式性にとらわれるのではなく、日本の造形の合理性 や機能性に加えて、精神性とも言うべきものを受容していたといえる。 日本の造形の抽象的性格唯彼の建築観に影響を与えていたのである。

また、ノイトラが日本にみた特質、すなわち地域固有の自然環境 や敷地一の呼店、そして伝統的な歴史や文化を没み取ろうとする姿勢 は、地域主義と共通するものである。このノイトラの地域主義的展開 については、更なる検証が必要であるが、これを単なる転向と考える 
だけでは不十分であると思われる。ノイトラの地域主義的展開は、彼 の日本に対する評価や理解を考え合わせることによって、より明確に 理解されうるのではないだろうか。すなわち最新のテクノロジーへの 依拠を前提とする態度は、モダニズムの機能主義や合理主義理論によ るものとみることができるが、地域の伝統や自然と建筑の関係性を抽 出し、継承しようとする姿勢は、欧州に由来するモダニズムの理論に 基づくというよりも、日本の特質を自己の建築観と照らし合わせて理 解した結果に基づく側面が大きかったと考えられる。それゆえに、， イトラにとって日本は大きな意味を持ちえたと考えられるのである。

謝辞＼cjkstart本稿をまとめるにあたり、京都工芸緎維大学教授、石田潤一郎 先生にご教示を賜りました。そして同校助手、笠原一人先生から貴重 な史料の提供とご助言を賜りました。また、カリフォルニア大学ロサ ンゼルス校教授のトーマス・ハインズ（Thomas S. Hines）先生には多 くのご教示をいただきました。ここに記して、感謝の意を表します。

\section{砫}

Modern Architecture: International Exhibition, The Museum of Modern Art, New York, 1932.

2 Arthur Drexler and Thomas S. Hines, The Architecture of Richard Neutra: From International Style to California Modern, The Museum of Modern Art, New York, 1982; Thomas S. Hines, Richard Neutra and the Search for Modern Architecture, Oxford University Press, 1982.

3 Dietrich Neumann edit., Richard Neutra's Windshield House, Harvard University Graduate School of Design, Harvard University Art Museums; Yale University Press, 2001; Stephen Leet, Richard Neutra's Miller House, Princeton Architectural Press, 2004; Sylvia Lavin, Form Follows Libido: Architecture and Richard Neutra in a Psychoanalytic Culture, MIT Press, 2005.

4 Alexander Tzonis, Lianne Lefaivre and Bruno Stagno, Tropical Architecture, Critical Regionalism in the Age of Globalization, Wiley-Academy, 2001, pp.35-40 Kenneth Frampton, Modern Architecture: a critical history, Thames and Hudson, revised edition, 1985, p.319. 中村敏男訳『現代建筑史』青土社 2003, p.551。

5 ノイトラと日本の関係について言及した既往研究としては Clay Lancaster, Japanese Influence in America, W. H. Rawls, 1963 や田中厚子「南カリフォルニ アにおける日本建築の影響と引き戸の導入」『建築史の回り舞台一時代とデ ザインを語る』彰国社 1999 などがある。

6 本稿は 2004 年度日本建築学会大会にて発表した論文「リチャード・ノイト ラの建築観と日本」にもとに、新たな知見を加えて書き改めたものである。 本稿の考察にあたって、当時の建築系の雑誌や新閣、カリフォルニア大学 ロサンゼルス校のノイトラ・アーカイブ(University of California, Los Angeles, Charles E. Young Library, Special Collection, Neutra Papers）に所藏されている 日本旅行時のスケッチやスクラップなどの瓷料収集と閲筧を行った。

7 上野伊三郎「ノイトラ氏老迎えて」『建築と社会』1952 年 7 月 pp.30-31

8 上野によれば、ロースは「目本古文化の大の愛好者」であったという。前 揭、上野伊三郎「うイトラ氏を迎えて」『建築と社会』1952 年 7 月 pp.30-31 最近の研究では、ロースが 1927 年までに建築の未来を考えるうえで、日本 建築に注目していたことが明らかにされている。クラウディア・デランク、 水藤龍彦・池田祐子訳『ドイツにおける〈日本二像〉』思文閣出版 2004, p.182

9 当時のウィーンの芸術に触れる機会を与えたのは、彼の姉ジョセフィーン (Josefine Neutra)であった。ジョセフィーンは芸術家であり、その夫は美術 館学芸員かつ美術史家であった。彼らはウィーンの芸術家たちに精通して いただけでなく、ノイトラとウィーンの先進的な芸術サークルへの橋渡し をしていた。彼らはノイトラにウィーン分離派の芸術家たち、特にエゴン シーレ、オスカー・ココシュカ、グスタフ・クリムトのアトリエを訪ねる 機会まで提供していた。Thomas S. Hines, op., cit., p.13

10 Foreword by Neutra, Heinz Geretsegger \& Max Peintner, Otto Wagner, 1841-1918, Pall Mall Press, 1970; ノイトラはウィーン世紀末芸術の状況を語るなかで クリムトを賞黄していたと述心゙ている。

11 小川信子, 田中厚子著『ビッグ・リトル・ノブ: ライトの弟子・女性建築 家土浦信子』ドメス出版 2001、ジュリア・ミーチ「フランク・ロイド・ラ イトと日本美術」『アメリカのジャポニスム展国際シンポジウム』世田谷美 術館 1991, p.30

12 Julia Meech, Frank Lloyd Wright and the Art of Japan, Japan Society: Harry N Abrams, 2001

13 上野伊三郎「ノイトラ氏」『インターナショナル建築』1930 年 8 月 p.15

14 Arthur Drexler and Thomas S. Hines, op. cit., p.51 ニューヨーク近代美術館の 学芸員であったドレクスラーはこの作品に日本の建築デザインとの共通性 をみている。それは日本の茶室に見られる絨細な柱梁の構造や桂離宫に見 られる柱の規則的なリズムの表現性であった。

15 David H. Engel, Japanese Gardens for Today, with a foreword by Richard Neutra, C.E. Tuttle, 1959
16 ヨハネス・ヴィーニンガー「我々は日本人から何を学びうるかー日本の芸 術と 1900 年前後のウィーン」『ウィーン世紀末日 セゾン美術館 1989 p.449 17 「建築美術の研究に来朝ノイトラ教授」『横浜毎日新報』1930 年 6 月 10 日

18 ノイトラ「新建築の意義と実際」『国際建築』1930年 7 月 pp.2-3

19 Neutra, Wie baut Amerika?: Gegenwartige Bauarbeit Amerikanischer Kreis, Stuttgart: Hoffmann, 1927; Amerika: Die Stilbildung des Neuen Bauens in den Vereinigten Staaten, Wien: Schroll, 1930

20 「大衆の手でいい家を多く作れノイトラ氏説く」『大阪毎日新閶』1930 年 6月 18 日。ノイトラは 1930 年に日本インターナショナル建筮会の国際会 負に名を連悋ている。

21 Ibid., p. 9

22 "Neutra Finds Our Skyscrapers Deny City Place in the Sunshine", New York Evening Post, January 12, 1931

23 Neutra Gegenwärtige Bauabeit in Japan, Die Form, 1931, Heft 1, pp.22-28; Japanische Wohnung. Ableitung. Schwiergkten, Die Form, 1931, Heft 3, pp.92-97; Neue Architektur in Japan, Die Form, Heft 9, 1931, pp.333-340

24 中尾保「ノイトラ氏と語る」『インターナショナル建築』1930 年 8 月 p.16

25 『インターナショナル建策』1930 年 8 月の編集後記「䕌感」にノイトラの 来日時の言動がまとめて記述されている。

26 上野伊三郎「ノイトラ氏」『インターナショナル建築』1930 年 8 月 p.15

27 Ibid.

28 Neutra, Life and Shape, Appleton-Century-Crofts, 1962, p.228

29 この点については、1931 年の『フォルム』声上で発表された論文でも同一 のことを語っていた。 Neutra, Japanische Wohnung. Ableitung. Schwiergkten, Die Form, 1931, Heft 3, pp.92-97

30 前稿にてノイトラの規格化に関して日本住宅に言及していたことについて 諭じた。玉田浩之，石田潤一郎「リチャード・ノイトラの初期住宅作品に おける設計手法について一-1920 年代及び 30 年代の実験的工業化住宅を中 心として一」日本建築学会計画系論文集 No. 587,pp.235-241, 2005 年 1 月

31 Neutra, Life and Shape, Appleton-Century-Crofts, 1962, p.227. ノイトラの来日 時の感想と興味の対象は概して一貫しており、この自伝の言説は彼の日本 への関心の高さと持綂性を物語っている。ただし、日本の「空間と自然」 に関する直接的な言及は、後述するように 1940 年代に入ってからである。

32 ここで述べられるノイトラの所感は、横浜に到着した時のことであること から 1930 年の初来日時を回想したものと考えられる。

33 Neutra, The Domestic Setting Today, Art in American Life and Education, National Society for Study on Education, Forth Year Book, 1941, pp.57-63

34 ノイトラは活動初期から、テクノロジーを活かす事を念頭においていた。 玉田浩之, 石田润一郎「1920 年代および 30 年代のリチャード・ノイトラの 建築思想におけるテクノロジーについて」日本建築学会計画系論文集 No. 574, pp.209-215, 2003 年 12 月

35 Ibid., p.58

36 Neutra, The Domestic Setting Today, Art in American Life and Education, National Society for Study on Education, Forth Year Book, 1941, p.59

37 Ibid., p.59

38 これは戦後に南カリフォルニアで広まる「アウトドア・リビング」に連な る考え方である。1940 年代の地域的な展開として見られるひとつの特質と もいえる。たとえは、以下の文献を参照されたい。 Modern is Regional, House and Garden, March 1941, pp.35-37

39 Neutra, Mystery and Realities of the Site, Morgan \& Morgan, 1951

40 Ibid., p. 56

41 Neutra, the Significance of the Setting, Architectural Review, December 1949, p.58 42 lbid.

43 ノイトラ「自然に帰れ」『建築と社会』1952 年 7 月 第 33 巻 pp.24-28

44 lbid.

45 この日本の自然観に対する注目は前掲の「フォルム」誌において、既に報 告されていた。そこでノイトラが着目した点は、日本人の立ち居振る舞いと 建築の関倸であった。初来日時のノイトラが建造物だけでなく、日常生活を 営む人物を熱心に描いていることからもその関心の高さがうかがえる。 Neutra, Japanische Wohnung. Ableitung. Schwiergkten, Die Form, 1931, Heft 3, pp 92-97。市本人の生活にみる榣やかな振る舞いと「軽い構造と薄い皮 膜」による住宅との間には合理的な関係があるとみていた。すなわちノイト ラは日本人の生活と住宅との関係に合理的な関連性を見出し、これを高く評 価していたのである。この点は以下の文献に詳しい。Neutra, Sound and Smell of Architecture, Progressive Architecture, November 1949, pp.65-66 「建築の音と におい」『国際建築』第 17 巻第 4 号 1950 年 10 月 pp.7-9

46 ノイトラ「リチャード・ノイトラ：日本の建築家諸君に』『国際建築』1952 年 2 月 pp.52-55.

47 lbid.

48 上野伊三郎はのちに「彼等（ノイトラの所庽した墺独機能主義グループ） はこれ (日本古美術)を精神的に取り入れて、外形上の模做に陷らなかった」 『建築と社会』1952 年 7 月 p.31 と指摘している。この指摘は、当時の日本 の建筑思潮との関連から考慮されるべき点があるが、ノイトラが日本美術に 関心を持つウィーンの集団から出発し、その後日本の造形を模做せず精神的 に取り入れた事実は、彼の日本受容のあり方を理解するうえで注目される。

图版出典 図 1: Arthur Drexler and Thomas S. Hines, The Architecture of Richard Neutra, Museum of Modern Art, New York, 1982, p.17; 図 2: Ibid., p.24; 図 3 Thomas S. Hines, Richard Neutra and the Search for Modern Architecture, Oxford University Press, 1982, p.16; 図 4: Ibid., p.24; 図 5 : Die Form, 1931 Heft.1, p.22

(2005年 7 月 8 日原稿受理, 2005 年 10 月 14 日採用決定 